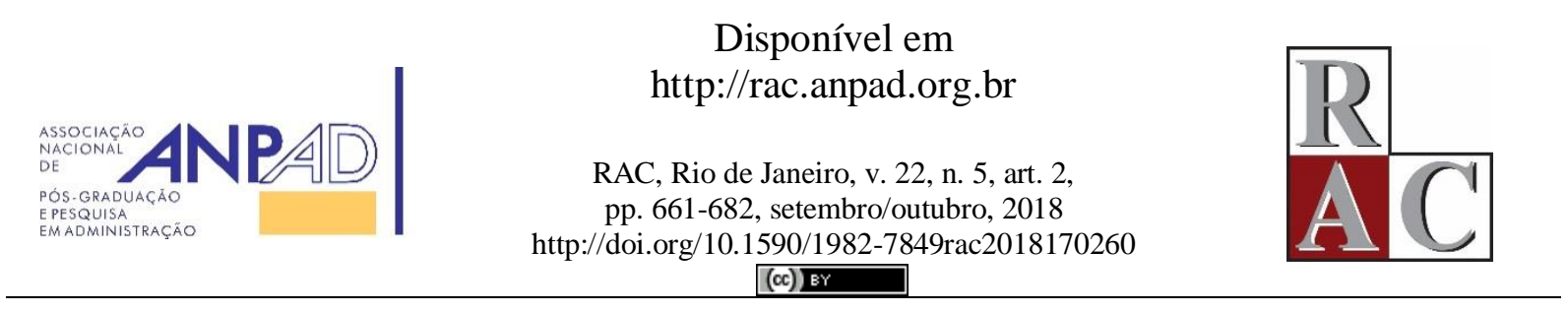

\title{
Lógica de Mercado Como Medida de Eficiência da Organização do Carnaval de Olinda
}

\author{
Market Logic as an Efficiency Measure of the Organization of Olinda's Carnival
}

Suélen Matozo Franco ${ }^{1}$

https://orcid.org/0000-0001-7835-9257

André Luiz Maranhão de Souza Leão ${ }^{1}$

iD http://orcid.org/0000-0002-7660-5845

Universidade Federal de Pernambuco, Departamento de Ciências Administrativas, Recife, PE, Brasil ${ }^{1}$

Artigo recebido em 03.08.2017. Última versão recebida em 09.02.2018. Aprovado em 22.07.2018. 


\title{
Resumo
}

O Carnaval de Olinda converteu-se num megaevento nas últimas décadas, revelando-se uma organização cada vez mais complexa à medida que uma lógica de mercado se insere e se intensifica. Essa difusão da lógica de mercado em diversas instâncias da vida pública é um fenômeno bastante associado às premissas do neoliberalismo. Nesse sentido, uma importante contribuição é a análise da racionalidade governamental empreendida por Michel Foucault, na medida em que sua obra remonta à emergência do pensamento liberal e à racionalidade a ele subjacente. O presente estudo investiga como a lógica do mercado é adotada no Carnaval de Olinda, tomando como base a análise de discurso sistematizada por Foucault. Para tanto, foi analisada toda a cobertura jornalística dos carnavais de 1986, 1996, 2006 e 2016 dos dois principais jornais de Pernambuco, que distam 10 anos entre si, no intuito de apreender as mudanças substanciais ao longo das décadas. Nossos achados apontam para uma busca de eficiência governamental por parte da municipalidade, tendo como premissa o modelo do homo xeconomicus e adotando tecnologias políticas voltadas para a mediação de interesses entre mercado e sociedade.

Palavras-chave: Carnaval de Olinda; governo; mercadização; homo æeconomicus

\begin{abstract}
Olinda's Carnival (Mardi Gras) has become a mega-event in the last decades, proving to be an increasingly complex organization in how market logic is inserted and intensified. This diffusion of market logic in several instances of public life is a phenomenon closely associated with the premises of neoliberalism. In this sense, an important contribution is the analysis of the governmental rationality undertaken by Michel Foucault, inasmuch as his work goes back to the emergence of liberal thought and the rationality underlying it. Present study investigates how market logic is adopted in Olinda's Carnival, based on discourse analysis as systematized by Foucault. Therefore, we analyzed the journalistic coverage of the 1986, 1996, 2006 and 2016 carnivals made by the two main Pernambuco newspapers. The 10-year gap between events was intended to enable the apprehension of substantial changes over the three decades. Our findings point to a quest for governmental efficiency on the part of the municipality, based on the homo economicus model and adopting political technologies aimed at mediating interests between market and society.
\end{abstract}

Keywords: Olinda's Carnival; government; marketization; homo economicus.

JEL codes: Z11, D6, N26. 


\section{Introdução}

Nas últimas décadas, a magnitude do Carnaval no Brasil tem movimentado uma verdadeira indústria do entretenimento e possibilitado investigações as mais diversas. De acordo com Hollanda (2013), esse festejo não só possibilita compreender a relação Estado-mercado-sociedade como também mídia, poder público, turismo, cultura, política, dentre outros. Miguez (2012) alerta que o modelo empresarial que tomou o Carnaval nas últimas décadas requer políticas específicas que possibilitem compreender a complexidade do festejo, que envolve uma miríade de agentes; evitar que a dimensão econômico-mercantil venha a suplantar a simbólico-cultural; e que os grandes oligopólios do entretenimento não excluam nem fragilizem ainda mais as pequenas agremiações, possibilitando uma repartição mais justa dos resultados econômicos.

Dentre os grandes carnavais do Brasil convertidos em megaeventos, destacamos o Carnaval de Olinda, município vizinho a Recife, capital do Estado de Pernambuco. Olinda é Patrimônio Cultural da Humanidade, título que recebeu da Organização das Nações Unidas para a Educação, Ciência e Cultura (Unesco), em 1992, além de ter sido eleita a primeira Capital Brasileira da Cultura, no ano de 2005. Seu Carnaval é considerado um dos mais famosos do Brasil e um dos pontos altos da vida cultural do município, reunindo mais de um milhão de foliões por dia (Harchambois \& Pontual, 2007). Dada a importância que o festejo representa para o município, existem, no âmbito da Administração Pública municipal, dois instrumentos que regem sua realização: a Lei $n^{\circ} 5.306$ de 2001, Lei do Carnaval, e o Plano Municipal da Cultura.

Müller (2015) define um megaevento como uma ocasião de duração fixa que atrai um grande número de visitantes, possui amplo alcance, proporciona custos elevados e exerce profundos impactos no ambiente e na população. Dessa forma, levando-se em consideração as quatro dimensões propostas pelo autor, podemos considerar o Carnaval de Olinda, no formato praticado nas últimas décadas, como um megaevento, tendo em vista os números referentes a investimentos, arrecadação e visitantes, bem como os impactos do período carnavalesco no bem-estar dos moradores do Sítio Histórico e no patrimônio.

Assim, diz-se que o Carnaval de Olinda surge como uma manifestação espontânea dos moradores da Cidade Alta, onde se localiza o Sítio Histórico, e, a partir da década de 1950, passa por um paulatino processo de profissionalização e municipalização, com a prefeitura subvencionando as agremiações e normatizando o festejo; a crescente importância da imprensa e dos formadores de opinião na década de 1960; e o Decreto Municipal que aboliu o modelo de passarelas e comissões julgadoras no limiar da década de 1970, um marco no sentido de estabelecer a identidade do festejo como Carnaval de rua (Ataíde, 1982). Essa profissionalização, tendo à frente a Prefeitura Municipal de Olinda (PMO), caminha lado a lado com a diversificação dos mecanismos de arrecadação e financiamento, bem como a ampliação da rede de agentes envolvidos. Nessa dinâmica, a década de 1990 é marcada pela consolidação das parcerias entre PMO e entidades privadas, sob a forma de patrocínios, revelando a dimensão mercadológica que se intensifica com o passar dos anos (Harchambois \& Pontual, 2007) e molda consideravelmente a feição do festejo.

O caráter de megaevento e meganegócio que permeia em maior ou menor medida diversos carnavais do Brasil - a exemplo de Salvador (BA), Rio de Janeiro (RJ), Recife (PE) e Olinda (PE) faz do festejo um complexo organizacional cujas partes são cada vez mais intricadas (Hollanda, 2013). Um estudo realizado por Santos (2010) acerca da relação entre o Carnaval e a gestão pública revelou, em três capitais (Recife, Rio de Janeiro e Salvador), uma complexa estrutura organizacional, incluindo secretarias, patrocinadores, artistas e grupos empresariais privados, bem como forte orientação para resultados econômicos, sobretudo aqueles decorrentes da visibilidade turística dos festejos. Este último aspecto remete a um fenômeno amplamente discutido nos estudos críticos em marketing, a mercadização (tradução livre de marketization). Tal conceito diz respeito à difusão da lógica de mercado nas mais diversas esferas da vida em sociedade (McAlexander, Dufault, Martin, \& Schouten, 2014; Özgün, Dholakia, \& Atik, 2017), inclusive à produção e à circulação de produtos culturais (Chantepie, Becut, 
\& Ratiu, 2015) e às práticas de gestão pública em várias esferas, quando pautadas por mecanismos de ação típicos do mercado e de ambientes competitivos (Hansen \& Lindholst, 2016). Para Özgün, Dholakia e Atik (2017), um importante aporte para a crítica a esse fenômeno é a análise da governabilidade neoliberal empreendida por Michel Foucault, na medida em que esse fenômeno não é problematizado na contemporaneidade, mas a partir de uma análise histórica que reconhece a emergência do mercado não de forma reificada, mas como um dispositivo político que surge de mudanças históricas.

A obra de Foucault permite traçar a emergência do neoliberalismo, situando historicamente uma nova relação entre mercado e objetivos de governo, em que este último tem naquele um local de formação de verdade (Yates, 2015). Para o filósofo, interessa não só o regime político em si, mas, principalmente, o sujeito desse regime, sua condição ambígua de sujeito e objeto de relações de saberpoder (Stival, 2016).

É na minuciosa análise da relação poder-saber-corpo que Michel Foucault investiga a emergência de uma nova racionalidade, na qual a economia política desponta como o corpo de conhecimento pelo qual os Estados articulam população e riqueza por meio dos eixos da produção, da circulação e do consumo (Foucault, 2008a). Tal discussão, posteriormente, insere-se num quadro de racionalidade liberal, em que o mercado desponta como um lugar de formação de verdade (Flew, 2015) que legitima práticas do Estado; nesse contexto, surge o homo œeconomicus, o sujeito de interesse, aquele para o qual a racionalidade econômica perpassa as mais diversas dimensões do cotidiano; esse sujeito não se pode sobrepor ao de direito (Ashenden, 2015), o que requer um quadro de referência para pensar a heterogeneidade desses dois sujeitos: a sociedade civil, como espaço de mediação em que é possível contemplar as demandas do social e as especificidades do econômico (Foucault, 2008b).

Miguez (2012), a respeito do Carnaval baiano, reconhece o festejo como produto e mercado, simultaneamente, com uma lógica organizacional complexa e uma enorme capacidade de geração de riquezas. A respeito dessa infiltração da lógica de mercado no caso olindense, lançamos a seguinte questão: Como a lógica do mercado é adotada na organização do Carnaval de Olinda? Por organização, entendemos aqui processo, a dinâmica que envolve gestão pública, líderes de agremiações e associações de classe, empresas privadas e agentes diversos, muito embora possamos adiantar que, em nossos achados, revela-se fortemente um protagonismo da Prefeitura Municipal, em torno da qual gravitam e articulam-se diversos outros agentes. Assim, partimos da reflexão foucaultiana sobre o poder, tomando como referência homo oeconomicus e a premissa da eficiência governamental e de suas tecnologias políticas para compreender as tensões Estado-mercado-sociedade civil que se configuram com esse processo. Para tanto, analisamos cobertura jornalística do Carnaval olindense nos dois principais jornais impressos do Estado de Pernambuco, na íntegra, dos anos de 1986, 1996, 2006 e 2016, eventos que distam uma década entre si, permitindo apreender as transformações ao longo do período analisado, bem como a historicidade das configurações de poder em consonância com o aporte foucaultiano deste estudo.

O presente estudo justifica-se primeiramente por pretender-se uma contribuição ao crescente interesse que o campo dos estudos organizacionais tem demonstrado pelos Carnavais do Brasil (vide Hollanda, 2013), abordando um carnaval considerado como um dos maiores do País, alvo de grande visibilidade midiática, mas ainda incipiente no que concerne à produção acadêmica. Este trabalho é composto das seguintes seções: uma breve descrição do Carnaval de Olinda, com suas transformações e seus incidentes críticos; a descrição detalhada da trilha metodológica; a apresentação dos resultados, num formato que mescla a descrição dos achados, e a discussão teórica destes - optamos por trazer a teoria concomitantemente aos achados por se tratar de um estudo de caráter parcialmente indutivo e para preservar a fluidez da discussão; por fim, apresentamos nossas considerações finais. 


\section{Carnaval de Olinda: Quatro Décadas de Transformação}

No município de Olinda, que dista menos de $7 \mathrm{~km}$ do Recife, o Carnaval de rua é herdeiro do entrudo, e suas primeiras expressões culturais coincidem com o surgimento das agremiações carnavalescas, no início do século XX (Harchambois \& Pontual, 2007), por iniciativa de famílias moradoras ou veranistas do Sítio Histórico (Ataíde, 1982). A Cidade Alta, que corresponde ao Sítio Histórico, é o centro aglutinador, local onde o festejo ocorre com mais intensidade (Leal, 2008).

Atribui-se à década de 1950 o início de um processo de profissionalização e municipalização do Carnaval de Olinda: a Câmara e a Prefeitura Municipal do município passaram a oferecer ajuda financeira às agremiações, declinando da prática de colaboração popular às entidades carnavalescas (Ataíde, 1982) que, contudo, não deixou de existir, permanecendo até os dias atuais, sob a forma de eventos para arrecadação de fundos, como feijoadas, bingos, rifas, vendas de camisas e souvenires, etc. Para muitos blocos, as atuais dimensões do Carnaval demandam orquestras maiores, cordões mais organizados e, consequentemente, mais recursos financeiros, que são obtidos ora via subvenção, ora via patrocínio de empresas privadas, ora via foliões, através de eventos ou compra de itens.

A década de 1960 foi marcada por dois impulsionadores importantes para a projeção do Carnaval olindense: o primeiro foi o crescimento dos meios de comunicação e o seu reconhecimento como formadores efetivos de opinião pública levaram a Prefeitura Municipal a inaugurar, em 1968, sua Assessoria de Imprensa, mobilizando esforços para dar ao Carnaval uma repercussão nacional - essa assessoria passou a operar em tempo integral durante o período carnavalesco a partir de 1976; o segundo aspecto, por sua vez, deu-se com a construção do Complexo Rodoviário de Salgadinho, aproximando Olinda da vizinha Recife e atraindo um contingente de foliões cada vez maior (Ataíde, 1982).

A década de 1970 foi marcada pela abolição das comissões julgadoras, das passarelas e dos palanques no Sítio Histórico, bem como com um engajamento mais efetivo dos próprios moradores na organização do festejo (Harchambois \& Pontual, 2007). Já na década de 1980, a duração do festejo foi oficialmente ampliada pelo Decreto $n^{\circ} 002$ (1981), do então Prefeito Germano Coelho, determinando como evento de início oficial do Carnaval fosse o desfile das Virgens de Bairro Novo, no domingo anterior ao de Carnaval, estendendo-se por toda a semana pré-carnavalesca, com ensaios gerais e acertos de marcha das agremiações, e encerrando-se oficialmente na Quarta-feira de Cinzas, com o desfile do Bacalhau do Batata (Ataíde, 1982).

Mesmo com a delimitação temporal do festejo, não é de hoje que uma atmosfera festiva se instala nas cidades com bastante antecedência, seja pelo aquecimento do comércio e dos serviços, seja pelas prévias materializadas nos ensaios de blocos e nas diversões carnavalescas promovidas no período anterior ao festejo (Araújo, 1996). Hoje, embora o calendário festivo oficial compreenda o início imediatamente após o término do Dia de Reis, quando o ciclo natalino é oficialmente encerrado (Leal, 2008), o período de ensaios abertos, que proporciona não só entretenimento aos brincantes, mas também dinamiza a economia do Carnaval (seja pela venda de itens dos respectivos clubes, seja pela intensa movimentação de ambulantes) já tem início mesmo antes do ciclo natalino. Isso revela a importante dimensão mercadológica que permeia o festejo, num movimento que se intensifica desde a década de 1990, por meio de parcerias entre a Prefeitura Municipal e as entidades privadas, na forma de patrocinadores (Harchambois \& Pontual, 2007).

Muitas das mudanças que marcaram a transição dos anos 1970 para os anos 1980, e, portanto, o novo formato de festejo instituído, são creditadas ao projeto de fortalecer do Sítio Histórico como polo cultural e turístico do então prefeito Germano Coelho (MDB), projeto esse que teve continuidade com seu sucessor José Arnaldo Amaral (PMDB), no cargo entre os anos de 1983 e 1989 (Barreto, 2008). Na década seguinte, entre os anos de 1993 e 1996, Germano (PMDB) foi novamente eleito prefeito do município. Já nos anos 2000, Luciana Santos (PCdoB) exerceu dois mandatos consecutivos, de 2001 a 2008, sucedida por Renildo Calheiros, do mesmo partido, que também exerceu dois mandatos, entre 2009 e 2016. 
Por outro lado, as sucessivas mudanças no sentido de profissionalizar o Carnaval olindense não podem ser observadas dissociadas de um plano mais amplo, o do Carnaval no Brasil. O Carnaval foi facilmente apropriado pelo projeto de construção de uma identidade nacional e de consagração de uma cultura autêntica, em curso desde a transição do século XIX para o XX, numa tentativa de revestir o Carnaval brasileiro de uma tradição, sendo este um conceito que aglutinaria elementos de origens diversas, nem sempre compatíveis, ou mesmo suficientemente antigos (Queiroz, 1992). Esse projeto, por sua vez, pressupunha um ideal unificado de Carnaval que, em vez de contemplar as peculiaridades, sobrepunha o modelo carioca aos demais folguedos, não sem resistências e amálgamas diversos (Ferreira, 2005). Farias (2006) destaca, ainda, o mito da comunhão, democracia e espontaneidade atribuído ao festejo (em sua análise, o carioca, mas que pode ser estendido a diversos carnavais urbanos) em materiais publicitários, sobretudo aqueles voltados para o turismo.

Data de 2001, início da gestão da Prefeita Luciana Santos, a Lei do Carnaval. Por esse instrumento, diversos procedimentos necessários à realização do festejo foram formalizados, a exemplo dos mecanismos de subvenção às agremiações, bem como as condições de elegibilidade destas, o relacionamento com os patrocinadores e a normatização do comércio de bebidas e alimentos no perímetro da folia, bem como de publicidade, vedada para empresas concorrentes das patrocinadoras oficiais (Lei $\left.{ }^{\circ} 5.306,2001\right)$.

A realização do Carnaval em Olinda também é orientada pelo Plano Municipal de Cultura, que define a intensa participação popular como a principal característica desse festejo. Além disso, o evento é visto como uma importante atividade econômica, inclusive pelo incremento ao turismo. No ano de 2016, o município recebeu 2,8 milhões de foliões, e aproximadamente $\mathrm{R} \$ 190$ milhões foram injetados na economia local, tendo a rede hoteleira obtido $98 \%$ de ocupação (Secretaria de Comunicação, 2016). No entanto, a questão de preservação do patrimônio material, sobretudo o casario, é bastante problemática, na medida em que, embora a Lei do Carnaval e o Plano Municipal apontem essa preservação como um importante eixo, Harchambois e Pontual (2007) ressaltam as ameaças ao patrimônio materializadas no grande fluxo de pessoas, na geração de resíduos, na poluição sonora e no comprometimento do casario em virtude da concentração de pessoas e das vibrações produzidas.

Outro aspecto problemático é que, embora a participação popular seja um importante eixo previsto em ambos os instrumentos e promovida pelo próprio Poder Público como a principal característica do Carnaval olindense, ainda há diversos conflitos entre interesses dos brincantes e de outros agentes envolvidos no processo. Tais conflitos envolvem não só a relação entre os mecanismos de financiamento e a própria identidade do festejo, como também o bem-estar dos moradores do perímetro da folia, a prestação de serviços públicos (tais como segurança e saneamento) e a própria configuração do espaço público durante a folia, conforme podemos observar nos achados a seguir.

A crescente importância dos mecanismos de patrocínio, que se consolidaram na década de 1990 (Harchambois \& Pontual, 2007), não foi uma exclusividade do Carnaval olindense. Santos (2010) destaca o peso que as entidades privadas exerceram nos festejos carnavalescos, mencionando inclusive a possibilidade de um patrocinador obter duplo ganho: de um lado, isenção fiscal via Lei Rouanet; de outro, faturamento sobre a venda de produtos exclusivos do patrocinador, a exemplo da Ambev no Carnaval do Recife em 2003. A Lei no 8.313 (1991), ou Lei Rouanet, visa obter o apoio da iniciativa privada no setor cultural, sendo a renúncia fiscal um dos seus principais mecanismos, e tem, no Carnaval, um de seus eixos. No entanto, dentre as críticas feitas a esse instrumento, destacam-se a redução da cultura ao status de mercadoria e do recurso midiático, bem como a concentração demasiada em algumas regiões, como o Sudeste (Brasileiro, 2016).

Em Olinda, embora a figura do patrocinador responda por um percentual significativo do financiamento (em 2016, mais de 50\% coube a uma marca de bebidas, segundo o então prefeito), a relação com entidades privadas, mesmo regulamentada por lei, pode ser alvo de conflitos com a sociedade civil. Foi o que aconteceu em 2015, com debates acerca da instalação de polos privados de animação (camarotes) no Sítio Histórico. Em 2015, houve alterações na Lei do Carnaval, proibindo a instalação, após consulta de representantes da sociedade civil e de entidades sociais. Após uma tentativa de anular essa decisão a favor dos empresários, a sociedade civil organizada pressionou a prefeitura 
(expondo na rede social Facebook o nome dos vereadores que votaram a favor dos empresários) e conseguiu reverter, mantendo a proibição dos camarotes no perímetro do Sítio Histórico.

\section{Procedimentos Metodológicos}

A presente investigação é de caráter pós-estruturalista, qualitativo e, no que concerne à utilização da teoria, parcialmente indutivo, pois aqui a teoria consiste numa lente pela qual interpretamos o fenômeno e, a partir dela, formulamos categorias empíricas (Leão, Mello, \& Vieira, 2009), que não existem a priori, mas emergem da interpretação do fenômeno à luz do aporte teórico.

Esse aporte, por sua vez, é o pensamento de Michel Foucault, que provê este estudo tanto da lente teórica quanto da trilha metodológica. De acordo com Thiry-Cherques (2010), a obra do filósofo propicia a interpretação de fenômenos os mais diversos sob a tríade poder-saber-corpo, ainda que suas investigações se detivessem em objetos específicos, sendo justamente a inter-relação entre esses três elementos (saber, poder e corpo) a lente que nos orientou na investigação do fenômeno em estudo.

De acordo com Dreyfus e Rabinow (2011), epistemologicamente podemos situar a obra de Foucault em duas vertentes, sendo a primeira delas, arqueologia, dedicada à compreensão da constituição dos saberes, para a qual se vale de elementos de uma análise de discurso, enquanto a segunda, genealogia, ultrapassa as realidades e as práticas discursivas de modo a investigar as relações de poder e subjetivação. Em ambos os casos, o filósofo admite saber e poder como elementos indissociáveis e historicamente construídos (Stival, 2016).

O presente estudo caracteriza-se como uma análise de discurso, uma vez que acessa precipuamente práticas discursivas. Para tanto, valemo-nos do método apresentado por Foucault em sua obra Arqueologia do saber, que constitui uma análise de discurso (Dreyfus \& Rabinow, 2011), doravante referida aqui como Análise de Discurso Foucaultiana (ADF).

A ADF é o processo sistemático pelo qual um discurso tem suas condições de formação e existência investigadas de modo a apreender suas regularidades e o sistema geral no qual este se insere e constitui (Foucault, 2014a). Discurso, por sua vez, pode ser definido como um complexo de enunciados regidos pelas mesmas regras de funcionamento, cuja análise acessa, para além dessas condições as realidades não discursivas (Thiry-Cherques, 2010).

A primeira etapa da presente análise foi a constituição de um arquivo, que, segundo ThiryCherques (2010), constitui-se num conjunto de documentos literários ou não que remontam a determinada época (Thiry-Cherques, 2010). Para o presente estudo, fixamos o Carnaval de 2016 como ponto de partida e recuamos temporalmente à década de 1980, que marca a emergência de uma nova dinâmica, dos pontos de vista organizacional e mercadológico, na concepção do festejo, conforme pesquisa bibliográfica prévia. A partir de 2016, analisamos a cobertura jornalística dos dois principais jornais do Estado sobre Carnaval por década, permitindo um intervalo de 10 anos, intervalo este que permitiu uma visão panorâmica das transformações ocorridas desde o incidente crítico. A opção pelos jornais Diário de Pernambuco e Jornal do Commercio deve-se ao fato de serem os únicos em circulação durante todo o período estudado. Os documentos foram acessados em suporte físico, disponíveis na Biblioteca Pública do Estado de Pernambuco, e examinados na íntegra os exemplares do período entre $1^{\circ}$ de janeiro e o domingo subsequente ao término do Carnaval de cada ano, digitalizandose todas as matérias referentes ao Carnaval de Olinda (excluindo-se informes publicitários, anúncios, artigos de opinião e cartas do leitor), conforme Tabela 1. 
Tabela 1

Documentos Analisados por Período e Fonte

\begin{tabular}{clllllllllc}
\cline { 2 - 10 } & $\mathbf{1 9 8 6}$ & & $\mathbf{1 9 9 6}$ & \multicolumn{3}{c}{$\mathbf{2 0 0 6}$} & \multicolumn{3}{c}{$\mathbf{2 0 1 6}$} & \\
\cline { 2 - 10 } & Jan. & Fev. & Jan. & Fev. & Jan. & Fev. & Mar. & Jan. & Fev. & TOTAL \\
\hline DP & 16 & 30 & 25 & 121 & 28 & 38 & 07 & 25 & 25 & 315 \\
\hline JC & 19 & 21 & 20 & 64 & 16 & 47 & 07 & 28 & 25 & 247 \\
\hline Total & 35 & 61 & 45 & 185 & 44 & 85 & 14 & 53 & 50 & $\mathbf{5 6 2}$ \\
\hline
\end{tabular}

Nota. Fonte: Elaborada pelos autores.

O discurso jornalístico foi escolhido por serem os media reconhecidos pelo próprio Foucault (2014b) como um espaço de formação de uma consciência social e, ao mesmo tempo, constrangidos por questões de ordem econômica e política. Seu papel é, portanto, fundamental nos jogos saber-poder, na medida em que propicia uma espécie de "agendamento de mundo" (Tucherman, 2007, p. 109). A opção por compor o arquivo exclusivamente do discurso jornalístico impresso de caráter massivo foi motivada pela necessidade de manter a homogeneidade dos dados. Isso porque, a partir da década de 2000, podemos observar uma queda considerável no volume de dados coletados, muito embora a cobertura jornalística tenha aumentado progressivamente nessas décadas. Isso se deve à diversificação de suportes após a década de 2000, quando o jornalismo on-line passa a ocupar-se de um volume considerável da cobertura. Nas últimas décadas estudadas, cresce a cobertura do jornalismo on-line, muitas vezes com notícias em tempo real e interativas, porém gerando dados muito heterogêneos em relação à totalidade do arquivo, tendo sido, portanto, desconsiderados.

A organização dos documentos e a identificação de categorias analíticas foi realizada com auxílio do software NVivo versão 10. Separados os documentos por fonte (jornal) e período (mês e ano), a primeira etapa de análise consistiu na identificação dos elementos da ADF, a saber, nesta ordem, conforme sistematizado por Foucault (2014a): enunciados, sendo a menor unidade dos discursos, indivisível e passível de relacionar-se com unidades de igual caráter; funções enunciativas, modus operandi dos enunciados, ou seja, a forma como eles enunciam; regras de formação, condições de existência, manutenção, modificação, rarefação e desaparecimento das unidades do discurso; e, por fim, como ponto de chegada da análise, as formações discursivas, um complexo de enunciados cujos sistemas de dispersão, seus objetos, conceitos e temas obedecem a certa regularidade - em nossa análise, identificadas pelo feixe de relações entre enunciados, respectivas funções enunciativas e regras de formação. Foi a partir das formações discursivas que articulamos nossos achados empíricos à lente teórica, conforme apresentaremos a seguir.

\section{Apresentação dos Resultados}

A presente seção é estruturada da seguinte forma: apresentamos, primeiramente, as categorias empíricas identificadas em nossas análises; em seguida, um diagrama que ilustra como essas categorias se relacionam, compondo o feixe de relações que caracteriza as regularidades discursivas. Para facilitar o entendimento desse diagrama (Figura 1), atribuímos códigos alfanuméricos às categorias empíricas que substituem a categoria por extenso no diagrama. Como a presente análise levou em consideração o aspecto temporal e as mudanças que ocorreram no período analisado, cada enunciado apresenta uma indicação do(s) ano(s) em que foi encontrado, permitindo apreender como os discursos se transformam ao longo das décadas.

Após a apresentação das categorias e respectivas inter-relações, realizamos uma discussão densa e detalhada dos achados, na qual evocamos a teoria à medida que cada feixe de relações aponta para pontos de articulação entre nossa lente teórica e achados empíricos. Optamos por evocar a teoria na 
discussão dos achados em consonância com o caráter parcialmente indutivo deste estudo e como recurso para preservar a fluidez de tais achados, sem separar aspectos descritivos da respectiva reflexão teórica.

\section{Constituição da formação discursiva}

Nossa análise evidenciou 39 enunciados, dez funções e três regras de formação, apresentados com seus respectivos códigos, na Tabela 2. A Figura 1 evidencia como esses elementos se relacionam constituindo os feixes de relações que compõem as formações discursivas. Na primeira linha, encontram-se os enunciados em retângulos, identificados pelos respectivos códigos. Sobre cada retângulo, encontra-se uma sequência de quadrículas que indicam o ano em que cada enunciado foi identificado no arquivo (referente aos campos preenchidos). Acima dos enunciados, linhas horizontais indicam como estes se inter-relacionam: quando essa relação é de natureza síncrona, ou seja, quando enunciados se explicam mutuamente, os retângulos são unidos por linhas simples; quando a relação é de natureza incidental, ou seja, enunciados que explicam os demais de um agrupamento, os retângulos são unidos por setas que incidem nos enunciados explicados. Na segunda linha, aparecem as funções enunciativas; na terceira, as regras de formação; e, por fim, a formação discursiva identificada. Setas oblíquas ligam enunciados, funções enunciativas, regras de formação e formação discursiva, nessa ordem, constituindo os feixes de relação que revelam como a formação é composta a partir dos seus elementos constitutivos.

Tabela 2

\section{Elementos Constitutivos da Formação Discursiva}

\begin{tabular}{ll}
\hline Enunciados \\
\hline E01 & $\begin{array}{l}\text { Agremiações carnavalescas de Olinda precisam moldar-se a um padrão estabelecido como tradicional } \\
\text { para sobreviver. }\end{array}$ \\
\hline E02 & Agremiações carnavalescas de Olinda segregam tipos de foliões. \\
\hline E03 & Camarotes representam uma ameaça ao Carnaval de rua. \\
\hline E04 & Agremiações e personagens folclóricos do Carnaval de Olinda são ordenados hierarquicamente. \\
\hline E05 & Categorias ocupacionais e instituições formam agremiações durante o Carnaval. \\
\hline E06 & Carnavalescos e artistas formam associações para se fortalecer na organização do evento. \\
\hline E07 & O Carnaval de Olinda segrega foliões genéricos. \\
\hline E08 & A precocidade cada vez maior das prévias gera uma sobrecarga para os serviços públicos. \\
\hline E09 & O Carnaval ameaça a integridade física do Patrimônio Histórico de Olinda. \\
\hline E10 & A infraestrutura urbana de Olinda é insuficiente para suportar a demanda do Carnaval. \\
\hline E11 & A PMO articula-se com a Administração Pública e a iniciativa privada para organizar o evento. \\
\hline E12 & O Carnaval provoca perturbação de ordem. \\
\hline E13 & O aumento de popularidade do Carnaval de Olinda ensejou o desenvolvimento de novas estratégias de \\
& organização. \\
\hline E14 & O Poder Público organiza e garante serviços essenciais para a folia. \\
\hline E15 & Tecnologias de monitoramento são utilizadas para garantir a manutenção de ordem no Carnaval de Olinda. \\
\hline E16 & O Carnaval requer ações educativas e de segurança para a população. \\
\hline E17 & Práticas punitivas são utilizadas para garantir a manutenção da ordem no Carnaval de Olinda. \\
\hline E18 & Bonecos gigantes exaltam personalidades no Carnaval de Olinda. \\
\hline
\end{tabular}




\section{Tabela 2 (continua)}

\section{Enunciados}

E19 A rivalidade entre as agremiações é profícua para o Carnaval olindense.

E20 Agremiações e personagens inovam suas performances para se tornarem mais atrativas.

E21 Agremiações criam versões infantis para iniciar as novas gerações na folia.

E22 Carnavalescos desenvolvem mecanismos de arrecadação para financiar os desfiles.

E23 O patrocínio é um importante mecanismo de financiamento do Carnaval de Olinda.

E24 O Carnaval de Olinda possui uma duração ampliada.

E25 O turismo em Olinda é intensificado no período carnavalesco.

E26 A imprensa presta um serviço relevante para o evento.

E27 Agremiações mudam suas rotinas para se beneficiarem de políticas públicas e investimentos privados.

E28 Agremiações e personagens ampliam seu mix de produtos para além das apresentações convencionais.

E29 O Carnaval de Olinda enseja oportunidades de geração de dividendos.

E30 O Carnaval de Olinda oferece atrações para públicos e preferências diversos.

E31 O Carnaval de Olinda é objeto de ações de branding da PMO.

E32 A atração e o acolhimento do turista são objetivos do Carnaval de Olinda.

E33 Carnaval de Olinda é um evento propício para a realização de ações de branding.

E34 O Carnaval de Olinda é gerido pela PMO como um empreendimento.

E35 O título de Primeira Capital Brasileira da Cultura agrega valor ao Carnaval de Olinda

E36 O Carnaval de Olinda proporciona arrecadação à municipalidade.

E37 O Carnaval de Olinda é um evento propício para ações de marketing eleitoral.

E38 Agremiações buscam obter notoriedade por meio das mídias de massa.

E39 Agremiações utilizam mídias digitais para estreitar relacionamentos com públicos de interesse.

\section{Funções}

F01 Descrever processos organizativos envolvidos na concepção do evento.

F02 Revelar aspectos infraestruturais da organização do evento.

F03 Aprimorar prestação de serviços de apoio ao Carnaval.

F04 Admitir potenciais consequências adversas do festejo.

F05 Proporcionar longevidade de manifestações carnavalescas.

F06 Ressaltar estímulo aos negócios promovido pelo festejo.

F07 Formatar o Carnaval de Olinda enquanto portfólio de produtos e serviços suplementares.

F08 Atribuir valor de marca ao festejo.

F09 Demonstrar potencial econômico do festejo.

F10 Atestar mídia como agente de visibilidade do evento.

\begin{tabular}{ll}
\hline \multicolumn{2}{l}{ Regras } \\
\hline R01 & Parceria estratégica \\
\hline R02 & Competência do Estado \\
\hline R03 & Dinâmica mercadológica \\
\hline
\end{tabular}

Nota. Fonte: Elaborada pelos autores.

RAC, Rio de Janeiro, v. 22, n. 5, art. 2, pp. 661-682, setembro/outubro, 2018, www.rac.anpad.org.br 


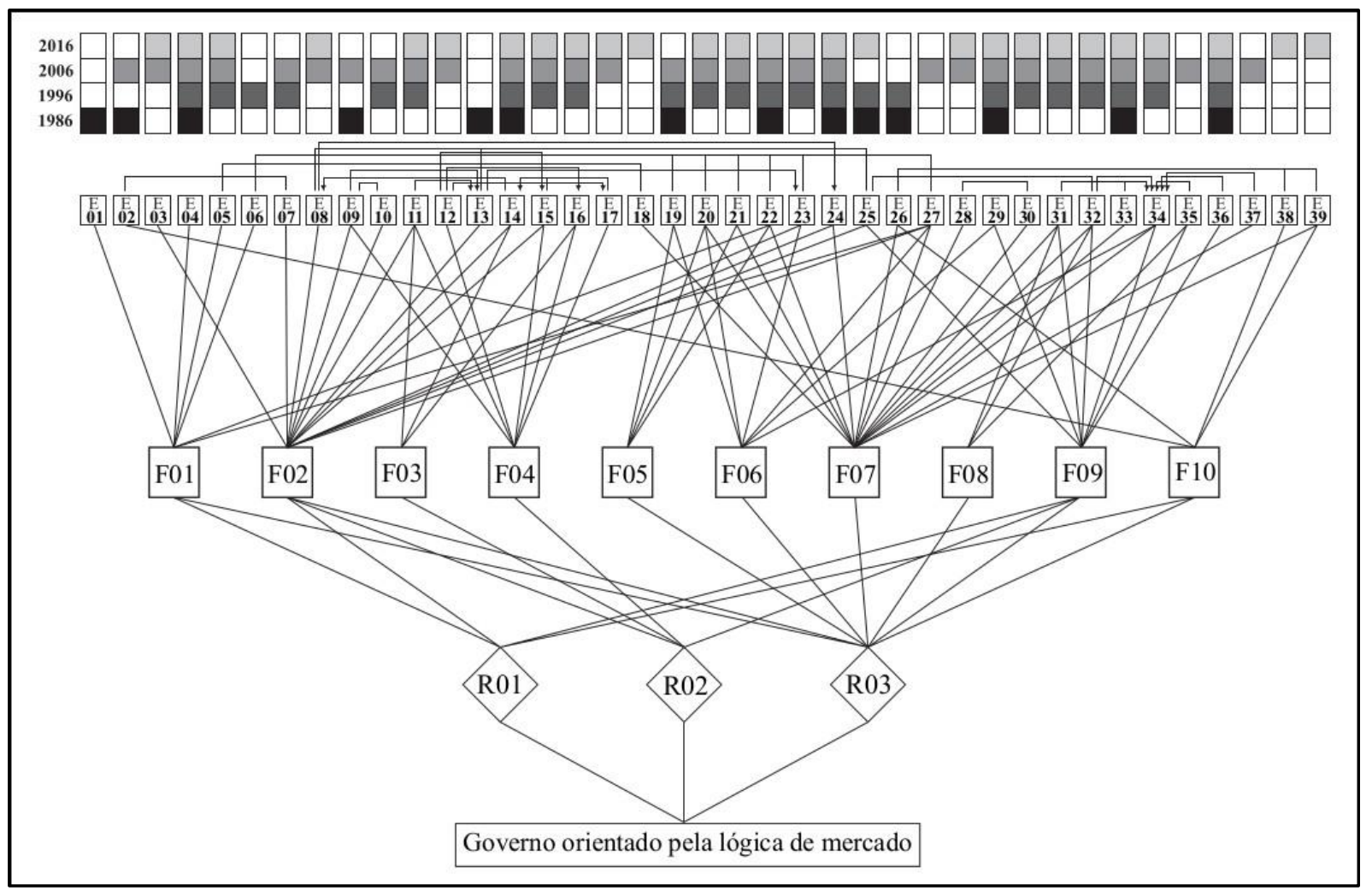

Figura 1. Governo Orientado Pela Lógica de Mercado: Mapa de Relações Fonte: Elaborada pelos autores.

Os feixes de relações apontam para a constituição de uma formação discursiva que denominamos Governo $^{(1)}$ orientado pela lógica de mercado. Nessa formação discursiva, as relações de mercado despontam como um importante marcador que orienta a ação da Administração Pública. Nesse sentido, o retorno sobre os investimentos termina por delinear a organização do Carnaval olindense. É válido ressalvar, nesse ponto, que não se trata de uma submissão da Administração Pública aos objetivos da iniciativa privada, mas sim à incorporação da lógica desta última em seu modus operandi, sendo o mercado o lócus de formação de verdade. Pierre Dardot e Christian Laval (como citado em Andrade \& Ota, 2015) alertam que não se trata de uma imposição da esfera econômica sobre as demais, mas uma extensão de racionalidade: desta forma, setores como a gestão pública e a produção cultural podem incorporar o modelo empresarial em suas práticas, orientando-as para as noções de concorrência e eficiência.

Dentre as regras, a que diz respeito ao mercado (R03) liga-se a oito funções, excluindo-se apenas duas, as que dizem respeito a melhorar a prestação de serviços no Carnaval (F03) e as que admitem riscos inerentes ao festejo (F04) - estas, por sua vez, ligam-se apenas à regra competência do Estado (R02). Os enunciados que incidem em R03 ocorrem predominantemente nas três últimas décadas analisadas, muito embora ocorram na década de 1980: neste caso, muitos enunciados que apontam para a dimensão mercadológica do festejo não revelam uma ação efetivamente orientada para o mercado, mas à presença dele como um meio para que se concretizem determinados objetivos do festejo. Por outro lado, os enunciados que se ligam à função do valor de marca (F08) ocorrem apenas nas três últimas décadas, assinalando a década de 1990 como o início de uma gestão de caráter empresarial do festejo. Por fim, a regra que remete às parcerias que viabilizam o festejo (R1) liga-se a quatro das dez funções, sendo uma delas referente às práticas de organização (F01); outra, à infraestrutura (F02); outra, à dimensão econômica (F09; e, por fim, ao papel da mídia (F10). Os constituintes dessa regra, de uma maneira geral, mostram-se relativamente estáveis ao longo das décadas, evidenciando a prática de se firmarem parcerias como uma característica da realização de um festejo dessa magnitude. 
Por outro lado, a questão da mídia sofre um deslocamento, atribuindo-se uma posição de destaque nessa parceria para a imprensa nas duas primeiras décadas analisadas e, na última década, a presença de novas mídias e uma posição mais ativa por parte das agremiações no sentido de obter visibilidade e estreitar relacionamento com seus públicos de interesse, promovendo ações que excedam a cobertura jornalística.

\section{Discussão dos resultados à luz da teoria}

A presente formação discursiva remete à uma busca de eficiência governamental, que se baseia no homo exconomicus como premissa do corpo social, operando técnicas de poder no sentido de mediar interesses entre mercado e sociedade. A discussão das tecnologias políticas do corpo na obra foucaultiana insere-se na moldura da instauração de um novo tipo de governo, notadamente com a emergência do mercantilismo. A técnica de governar demanda a constituição de saberes sobre o correto modo de dispor as coisas de forma que cumpram seus respectivos propósitos - a problemática da população coloca-se como um alvo desses saberes cuja inserção na economia é indissociável da geração de riquezas: uma economia política (Foucault, 2015). Aqui, é válida uma ressalva: ao abordar governo, Foucault o faz de forma deslocada da noção do Estado, de forma a desvincular as relações de poder das instituições (Avelino, 2016). Dessa forma, sempre que mencionarmos o termo governo, referimo-nos às técnicas e práticas, ainda que, no presente estudo, as práticas de um ente da Administração Pública apareçam de forma bastante central e contundente em nossos achados.

Ao problematizar esse governo sob uma racionalidade liberal, que implica um governo mínimo, uma instância se coloca estabelecendo a conexão entre esse governo e a economia política, como um lugar de formação de verdade: o mercado (Foucault, 2008b). Sob essa premissa, o mercado seria esse lócus no qual os efeitos do governo poderiam ser ajustados (Flew, 2015). Isso, contudo, não implica uma anulação do governo, mas a provisão, por parte do Estado, de condições para que o mercado obtenha autonomia.

Coexistente a esse governo enxuto e é, ao mesmo tempo, um requisito importante para que ele se concretize, a incorporação das práticas de governo pelos indivíduos, tornando-se cada vez mais autônomos e autogerenciáveis. Ao analisar o liberalismo americano, Foucault (2008b) identifica a tentativa de incorporar a perspectiva econômica a aspectos outros da vida cotidiana que extrapolariam a dimensão do mercado, tais como a vida familiar ou a educação; dessa forma, as mais diversas condutas seriam pensadas em termos econômicos, analisando a relação recursos-finalidades. Fundamental à inteligibilidade desse processo é o conceito de governabilidade, definido por Foucault (2015) como o conjunto de instituições, procedimentos, análises, reflexões, cálculos e táticas que permitam exercer uma forma específica e complexa de poder que tem a população como finalidade, tendo a economia política como forma principal de saber e dispositivos de segurança como instrumentos técnicos essenciais. Esse poder, chamado de governo, tornou-se, preeminente sobre todos os outros - soberania, disciplina, etc. - ao longo do tempo no Ocidente, como resultado do processo por meio do qual o Estado de justiça da Idade Média foi paulatinamente governamentalizado, tornando-se um Estado administrativo.

Para discutir a formação discursiva identificada nos dados à luz dessa base teórica, passemos a apresentar exemplos que ilustram feixes de relações a partir das três regras de formação, evocando, para cada descrição empírica, a respectiva discussão teórica.

\section{Parceria estratégica}

O elemento no qual essa racionalidade governamental se apoia, o indivíduo parceiro, governável e responsivo às modificações que se inserem em seu ambiente, é o homo æeconomicus (Foucault, 2008b). Esse sujeito seria, portanto, um empreendedor de si, ao aderir voluntariamente às demandas do mercado, ao mesmo tempo que responde ao seu interesse e que seu interesse converge com o de outros indivíduos (Avelino, 2016; Vallas \& Cummings, 2015). Nesse sentido, o indivíduo é, ao mesmo tempo, capital e força de trabalho, um empreendedor responsável pelo seu sucesso ou insucesso e autossuficiente (Calkin, 2015). Essa concepção de indivíduo seria o ponto de articulação entre a maximização da riqueza 
individual e da riqueza do Estado. Tal racionalidade governamental produz sujeitos capazes de se autoproduzirem e autogerirem, sendo a autonomia uma premissa pela qual o sistema funciona (Vallas \& Cummings, 2015). Para Foucault (2008b), esse homo æeconomicus é o sujeito do laissez-faire, aquele em quem o governo não deve tocar. Dessa forma, esses indivíduos se agrupam unidos pela convergência de interesses, gerando um aquecimento coletivo da economia (Ashenden, 2015).

Em nossas análises, a figura do mercado, com sua dinâmica peculiar, mostra-se de forma bastante contundente alinhada à ação do Estado. No exemplo a seguir, evidenciaremos como a essa busca, por eficiência, materializa-se a organização do Carnaval:

“"Nós já iniciamos os contatos com os possíveis patrocinadores e prometemos que este será um dos melhores carnavais de Olinda', garante o vice-presidente da Assoma, Paulo Pecado. Mesmo tendo autonomia para negociar valores e espaços com as empresas, a Assoma está atuando sob o comando da Comissão Consultiva do Carnaval, vinculada à Prefeitura de Olinda. A ideia da Assoma é desenvolver um trabalho preocupado com a qualidade, que valorize a cidade e atraia mais turistas para Olinda e para o Estado como um todo" (DP, jan. 1996, nº6).

A matéria da qual o trecho anterior foi extraído noticia a articulação dos músicos de Olinda numa associação (Assoma) e os esforços envidados por essa então criada organização para obter patrocínios. A passagem evidencia a articulação em associações de classe como mecanismo de maximização de resultados em torno de um objetivo comum (E06), que descreve os processos pelos quais agentes da organização atuam (F01). No entanto, ao mesmo tempo que a prática associativa fortalece a categoria dos músicos, a matéria revela a existência de uma moderação advinda do Poder Público: embora afirme autonomia da Assoma, sua atuação está vinculada à Comissão Consultiva do Carnaval, ou seja, em última instância subordinada à Prefeitura Municipal de Olinda. Isso revela a existência de uma articulação entre a PMO e agentes públicos e privados no sentido de viabilizar o evento (E11), indicando como essa rede de ação constitui a infraestrutura do evento (F02). Por outro lado, ao vincular o intuito de realizar um dos melhores carnavais de Olinda à valorização do município e à atração do turista para o município e até para o Estado, revela a importância do turismo nas decisões relativas ao festejo (E32), que demonstra os potenciais desdobramento econômicos deste (F09), na medida em que aponta para um horizonte de desenvolvimento local decorrente do sucesso no empreendimento do Carnaval. Tendo em vista que essa articulação tanto sana problemas de ordem infraestrutural quanto aprimora os mecanismos de negociação, configura uma parceria estratégica (R01).

O exemplo evidencia como os músicos figuram como agentes econômicos na medida em que, ao fazer convergir seus interesses com o da PMO no aprimoramento do evento, negociam melhores condições de trabalho para si e, ao mesmo tempo, colaboram para o ideal de eficiência do governo, sendo parceiros no processo de busca de patrocínio, um elemento que, como vimos, é basilar à infraestrutura do Carnaval de Olinda. O exemplo também materializa a premissa do empreendedor, o homo ceconomicus, que é, ao mesmo tempo, produtor e consumidor, responsável pela própria eficiência, cuja realização depende da suas autonomia, iniciativa e ação empreendedora (Cockayne, 2016; McGuigan, 2014). A ideia de um corpo social dotado de livre iniciativa amplia as bases de ação estratégica da PMO. Sabemos que a imprensa é uma importante parceira nas organizações de eventos, na medida em que atribui visibilidade e propicia um alcance cada vez maior. Tanto que a gestão municipal busca propiciar condições de trabalho para os operadores da imprensa. $\mathrm{O}$ exemplo a seguir data da década de 1990, marcada pela expansão do uso doméstico da Internet no Brasil, numa matéria intitulada Ladeiras on-line:

\footnotetext{
“A proposta é levar toda a irreverência da folia olindense para a telinha do computador. O site Olinda-online conterá informações, textos e imagens, distribuídos em capítulos, todos em permanente atualização, e uma página principal com informações gerais da produção e botões de navegação para lugares e assuntos específicos. Segundo o diretor João Paulo Quérrete, a empresa fechou um acordo com a Prefeitura de Olinda, que vai ceder um espaço na sede da administração municipal, com direito a uma linha digital exclusiva, direto para o True Net, o que permitirá maior velocidade no abastecimento de imagens e informações na rede. Ele garante também ter fechado um acordo com a produção da Rede Globo Nordeste, que vai ceder as imagens para serem digitalizadas e postas na Net. A Imagenharia promete que até o final da semana a home page contará com os links ... com dados sobre pousadas que ainda disponham de vagas
} 
para os foliões retardatários, onde comer e os melhores caminhos para se chegar à Cidade Alta, evitando os congestionamentos" (DP, fev. 1996, n 31).

O trecho acima é bastante emblemático da parceria estratégica (R01), na medida em que destaca o papel das empresas privadas Rede Globo e Imagenharia em articulação com a Prefeitura Municipal no sentido de proporcionar um maior alcance ao festejo, bem como prospectar foliões/consumidores. Nesse sentido, além da parceria firmada entre as empresas mencionadas e a PMO, também revela benefícios para as empresas que atuam nos segmentos turístico, hoteleiro e gastronômico. Dessa forma, a passagem demonstra a importância da imprensa na organização do evento (E26), que atesta o papel da mídia como agente de visibilidade do festejo (F10) e insere-se na infraestrutura necessária ao evento (F02), sendo a comunicação um serviço indispensável para que o festejo tenha adquirido tamanha proporção. Por sua vez, revela novamente a busca, pela PMO, de articulações tanto com outras esferas da Administração Pública quanto com a iniciativa privada (E11), o que também aponta para o provimento de serviços infraestruturais (F02). Por fim, ao vislumbrar com essa ação o fortalecimento tanto do turismo quanto dos negócios ligados à gastronomia, a passagem revela tanto a centralidade do turismo nos objetivos estratégicos do evento (E32), quanto um leque de oportunidades de geração de dividendos que o festejo enseja (E29), ambos indicando o potencial econômico do evento (F09).

\section{Competência do Estado}

A autonomia dos indivíduos no que tange à geração de riquezas evoca uma questão que se colocava como um impasse nessa racionalidade: se é verdade que o homo æeconomicus é movido pelo seu interesse, como sobrepor esse sujeito ao sujeito de direitos? Para Foucault (2008b), essa problemática revela a heterogeneidade desses dois sujeitos no que concerne ao poder político e, portanto, a dificuldade de sobreposição entre eles, na medida em que um age movido por seu interesse e o outro implicaria a renúncia parcial a certas liberdades para o cumprimento de um contrato que, por sua vez, existe para garantir condições seguras de exercício dessa liberdade. Por sua vez, num momento em que interesses individuais e coletivos colocam-se como um impasse, o governo procura equilibrar o jogo de interesses. O homo aconomicus é o empreendedor de si, o sujeito de interesse a quem o governo deve deixar fazer, mas ao mesmo tempo estimular (Avelino, 2016). A dificuldade de sobreposição entre o homo aeconomicus e o sujeito de direito requer um novo quadro de referência para a governabilidade: a sociedade civil, enquanto realidade na qual o homo øeconomicus se insere, na qual se torna possível um governo que administra o social, mas que respeita a especificidade da economia (Foucault, 2008b). A sociedade civil figura na obra foucaultiana não como uma realidade a priori, mas um conceito transacional, na medida em que ele empreende uma reflexão genealógica de como essa entidade se forma (Ashenden, 2015). Nesse sentido, uma vez instalada uma ordem de mercado que presume reciprocidade e conciliação diante de objetivos distintos e por vezes opostos, a coesão é possibilitada por um corpo de regras que, em vez de fixar fins específicos, limita a ação diante de conflitos potenciais (Dardot \& Laval, 2016).

Trazendo esse aspecto para nossas análises, foram observadas diversas situações em que o Estado foi chamado a intervir nos conflitos de interesses entre população e mercado, sobretudo quando as ações empreendidas por agentes deste último implicam o comprometimento do bem-estar de um ou mais grupos sociais. Com relação à mediação de interesses entre mercado e sociedade civil, podemos observar o exemplo a seguir.

\footnotetext{
“A festa Olinda Beer, marcada para o próximo dia 19 de fevereiro, não poderá ser realizada no terreno onde funcionava o antigo Quartel do Exército (PE), Bairro Novo, Olinda, Região Metropolitana do Recife. A Secretaria de Planejamento Urbano, Transporte e Meio Ambiente do município decidiu ontem negar o alvará de autorização para o evento. Segundo o órgão, a decisão foi tomada para evitar que se repitam os transtornos provocados pela festa no ano passado, quando as avenidas Carlos de Lima Cavalcanti, Getúlio Vargas e Marcos Freire, próximas ao quartel, ficaram congestionadas por mais de cinco horas. A prefeitura argumenta ainda que no mesmo dia das prévias ocorre o tradicional desfile das Virgens de Bairro Novo ... 'A cidade não suporta dois eventos grandes no mesmo dia ...' O empresário Augusto Acioli, um dos organizadores da festa, foi surpreendido com a proibição. Ele descarta o cancelamento do evento, que teve mais de 10 mil camisas-ingressos vendidas até a manhã de ontem" (JC, jan. 2006, nº 7).
} 
A matéria da qual o trecho acima foi extraído revela um impasse entre a Prefeitura Municipal e a promotora de um evento de grande porte vinculado ao calendário carnavalesco de Olinda. Aqui, faz-se importante uma breve digressão: o bloco As Virgens de Bairro Novo, realizada no domingo que antecede o domingo de Carnaval, é uma das mais tradicionais prévias carnavalescas de Olinda, a ponto de ter sido reconhecida por um decreto no ano de 1981 como o início oficial do Carnaval do município. A prévia Olinda Beer, por sua vez, consiste num mix de shows ofertados em estrutura fechada, que iniciou suas atividades na avenida onde ocorria o desfile das Virgens, como uma espécie de camarote, e passou por sucessivas mudanças de local em virtude do aumento significativo de demanda.

No trecho analisado, observamos que uma das principais razões do impasse advém de problemas infraestruturais versus demanda de investidores: o bairro onde os dois eventos aconteceriam não comporta dois eventos simultâneos, o que ele justifica mencionando o transtorno causado no ano anterior. Isso evidencia a insuficiência da infraestrutura urbana para suportar a demanda do Carnaval (E10), que aponta para os aspectos infraestruturais do evento (F02). Ao mesmo tempo, evidencia a capacidade de o festejo provocar perturbação de ordem (E12), admitindo suas potenciais consequências adversas (F04).

Por sua vez, também demonstra a incumbência da Prefeitura Municipal de deliberar sobre aspectos relativos ao ordenamento do festejo (E14), tendo em vista a necessidade de conciliar os interesses de investidores (organizadores da prévia), foliões de ambas as prévias e moradores da cidade, que não devem ter seus direitos de ir e vir comprometidos em função de um evento que a cidade sedia. Essa premissa tanto revela aspectos infraestruturais da organização do evento (F02) quanto uma tentativa de aprimoramento da prestação de serviços de apoio ao Carnaval (F03). Por fim, o impasse que se coloca também diz respeito à oferta de uma prévia que teve seu alvará de funcionamento negado, implicando um risco de prejuízo financeiro para o realizador do evento. Isso revela o Carnaval de Olinda como um festejo propício para a oferta de serviços de entretenimento por empresas privadas que veem no ciclo carnavalesco uma oportunidade de negócios, evidenciando o potencial de geração de dividendos do evento (E29), o que mais uma vez demonstra o potencial econômico do festejo (F09). É justamente essa potencial lucratividade, e consequentemente os investimentos que fizeram do Olinda Beer uma prévia dessa magnitude, que, no exemplo anterior, gera uma sobredemanda para a infraestrutura urbana do município e para os serviços públicos (no trecho extraído como exemplo, é mencionado o trânsito, mas a matéria completa também aborda poluição sonora, geração de resíduos e aumento da insegurança nas ruas). Essa incumbência de prover o festejo de condições de viabilidade, bem como o dever de mediar esses conflitos, estando constrangido de um lado pela demanda de bem-estar da sociedade e de outro pela demanda de mercado, apontam para a competência do Estado (R2).

Conforme observamos, cabe ao governo, neste caso em esfera municipal (PMO), prover o evento de condições para que os agentes privados realizem seus negócios, o que, no exemplo, materializa-se na concessão de alvará de funcionamento e de serviços de orientação de trânsito. Por outro lado, no momento em que os interesses dos atores privados acentuam ou mesmo, provocam a perturbação de ordem, sobrecarregando os serviços públicos e comprometendo, consequentemente, o bem-estar de parcela da população, o governo é chamado a intervir de forma mais contundente. Essa intervenção, apesar de beneficiar a prestação de serviços em detrimento dos objetivos empresariais, é pautada pela ideia de eficiência, na medida em que o Carnaval figura como um empreendimento do município cuja performance depende de seu empenho no provimento de infraestrutura e serviços. Em última instância, diante da insuficiência de recursos para a provisão de um empreendimento próprio (o tradicional bloco, bem como seus foliões, patrocinadores, turistas, etc.) e um empreendimento privado, a PMO opta por destinar seus serviços e sua infraestrutura à performance do seu empreendimento.

\section{Dinâmica mercadológica}

O potencial de geração de riquezas inerente ao evento não se materializa exclusivamente na ação da iniciativa privada. A própria gestão pública municipal, muitas vezes, opera sob essa premissa ao promover o festejo. Miguez (2012), a respeito da empresarização do Carnaval baiano, alerta-nos para o risco de que a dimensão econômico-mercantil do festejo, cuja existência é inquestionável, venha a 
suplantar a sua dimensão simbólico-cultural, convocando a gestão pública a formular políticas culturais que incidam sobre essa problemática.

Essa empresarização que o autor menciona é um processo comum aos diversos carnavais do país e, se é verdade que implica um estreitamento de relações cada vez maior com o setor empresarial, também pode apontar a inserção paulatina de sua lógica na dimensão cultural e até mesmo nos serviços públicos. Isso remete à generalização da economia nas mais diversas relações sociais (Foucault, 2008b), fazendo com que mesmo a gestão pública também compreenda uma manifestação cultural como negócio. Nesse sentido, podemos compreender o Carnaval de Olinda como um megaevento, na medida em que se configura como um evento de duração fixa que atrai um número considerável de visitantes, de localidades as mais diversas e distantes, implicando altos custos aos organizadores e um impacto na vida e na rotina das populações locais, bem como ao patrimônio (Müller, 2015). Isso demanda uma visão do festejo como um complexo de entradas e saídas, em que a atratividade e a estrutura oferecida demanda um elevado investimento e/ou parcerias. Essa condição de megaevento revela como a lógica do mercado permeia as mais diversas dimensões da vida pública, a exemplo de uma manifestação da cultura popular. Podemos observar esse processo no exemplo a seguir:

"Uma equipe de 65 pessoas está trabalhando a pleno vapor para montar o museu a céu aberto que integrará a cenografia do Carnaval de Olinda nesse ano. Na próxima segunda-feira, peças e elementos alegóricos começam a ser instalados em oito pontos distribuídos pela Cidade Alta, formando o que promete ser a maior decoração carnavalesca que a cidade já recebeu. O tema - Olinda: capital brasileira da cultura — será uma maneira de agradecer o título recebido e uma demonstração de seu merecimento" (DP, jan. 2006, nº 22).

O ano de 2006 foi o mandato de Olinda na categoria eletiva de Capital Brasileira da Cultura, tendo sido a primeira cidade a ser reconhecida com esse título. A honraria então deu a tônica de toda a campanha promocional do Carnaval de Olinda, desde a criação de um estandarte comemorativo do título, e consequente cerimônia de lançamento, até a criação de um edital para a seleção de um frevo inédito que versasse sobre a cidade. A matéria da qual o trecho foi extraído mostra os preparativos do Carnaval 2006 empreendidos pela Prefeitura Municipal.

No trecho analisado, evidenciamos que a Prefeitura trata o folguedo popular como um evento de grandes proporções por ela empreendido sob a premissa do desempenho (E34) - tanto que promete a maior decoração carnavalesca que a cidade já recebeu, assim como se empenha em assinalar que é de fato merecedora da honraria. Essa gestão não só demonstra o potencial econômico do festejo (F09), como também a formatação do Carnaval de Olinda enquanto portfólio de produtos e serviços suplementares (F07). Enquanto uma oferta de produtos e serviços de entretenimento, trata-se de um mix que se assenta numa marca, para a qual a PMO investe em ações de branding (E31), na medida em que a Prefeitura busca criar e adicionar valor ao festejo. $\mathrm{O}$ trecho também evidencia como a honraria obtida pelo município é capitalizada nesse sentido: dessa forma, todo o esforço de marketing em torno do festejo, que é convertido num mix, recebe um valor adicional. Esse valor adicional reside justamente no fato de o município ter sido eleito Primeira Capital Brasileira da Cultura (E35). Esses esforços de branding envidados pela PMO consistem numa tentativa de atribuir valor de marca ao Carnaval olindense (F08), o que mais uma vez demonstra o potencial econômico do festejo (F09). Essa ação de marketing aponta para uma dinâmica mercadológica (R3), cada vez mais indissociável do festejo.

O interesse é a medida da ação do homo æeeconomicus, e esse interesse tende a convergir com o de outros (Foucault, 2008b). No âmbito do Carnaval, podemos observar cada vez mais a aproximação de atores cujos propósitos são idênticos ou complementares. É o que aponta este exemplo, extraído de uma matéria de 2016, ano em que o orçamento do Carnaval, tanto oriundo do Poder Público quanto de investidores privados, foi comprometido em virtude da crise político-econômica. Na matéria, intitulada Carnaval da crise, uma agremiação tradicional de Olinda recorre a uma solução inusitada para a insuficiência de recursos:

“O bloco Mulher na Vara, que sai há 22 anos pelas ruas de Olinda, viu sumirem os patrocinadores que ajudariam a bancar os gastos com as prévias e a realizar as prévias. 'Começamos a nos reunir em maio para organizar o Carnaval. $\mathrm{O}$ ano foi passando e os patrocinadores foram desistindo, dizendo que a crise estava apertando. Até que tivemos a ideia de fazer uma festa colaborativa', explica Eduarda Casanova, 
colaboradora e membro da diretoria do bloco. O modelo adotado foi de prévia continuada, realizada todos os sábados até o Carnaval, no Garage Food Truck, espaço onde várias marcas desse modelo de negócio se reúnem no Espinheiro, bairro da Zona Norte do Recife. 'Para eles, é interessante também, porque atraímos mais público, e para nós, porque temos um lugar para realizar a prévia', explica Eduarda” (JC, jan. 2016, $\left.\mathrm{n}^{\mathrm{o}} 16\right)$.

A passagem evidencia a importância da figura do patrocinador, mas também a ação dos dirigentes de agremiações no sentido de manterem a continuidade do bloco, optando por envolve-lo em um novo modelo de negócios. Dessa forma, a agremiação firma uma parceria que resulta num mix de entretenimento e gastronomia: o bloco realiza sua prévia num Garage Food, uma solução inusitada, na medida em que insere a agremiação num ambiente distinto da tradicional ladeira ou dos bailes de prévias, comuns para arrecadação de verba. Com isso, a marca Mulher na Vara proporciona visibilidade ao negócio local, e a infraestrutura do negócio permite a realização das prévias, bem como favorece a venda de itens do bloco, o que visa ao financiamento do desfile.

A passagem mostra a desistência dos patrocinadores como o incidente crítico que leva os diretores a optarem por um modelo de prévia distinto, dada a importância do patrocínio (E23) tanto na ação do Poder Público quanto nas agremiações, o que aponta não só o estímulo aos negócios de naturezas diversas proporcionado pelo festejo (F06) quanto a criação de novos processos de se organizar (F01). A inserção desse negócio em um esquema colaborativo no qual a prévia se converte num mix de consumo (E28) - envolvendo gastronomia, entretenimento, bem como espaço de compras —, rompendo com os formatos convencionais (por convencionais, entendemos os desfiles ao ar livre e os bailes de prévias), confere ao Carnaval de Olinda um caráter de porftólio de produtos e serviços suplementares (F07). Por fim, a resistência dos carnavalescos às oscilações financeiras evidencia a prática de desenvolver mecanismos para arrecadar os recursos necessários aos desfiles (E06), demonstrando um compromisso desses agentes com a longevidade de suas agremiações (F05). Essa inserção dos negócios colaborativos na prática organizativa de uma agremiação carnavalesca aponta para a dinâmica mercadológica que perpassa o festejo (R03).

Como já discutimos, a prática da prefeitura de subvencionar as agremiações não declinou os mecanismos de financiamento delas, seja pela insuficiência e por vezes atrasos nas subvenções, seja pelos critérios de elegibilidade previstos na Lei do Carnaval, seja pelas dimensões que alguns blocos atingiram, requerendo mais recursos para financiar orquestras maiores e segurança privada. Por outro lado, os bailes de prévias - que, junto às vendas de itens e aos patrocínios de empresas privadas, são importantes mecanismos de financiamento - assumiram tamanha repercussão que hoje se constituem em um fim em si mesmos, a exemplo da agremiação Enquanto Isso na Sala da Justiça, cujo tradicional baile de prévia já se tornou um negócio.

Como pudemos observar, diante da magnitude que o festejo atingiu, as soluções para a sobrevivência de manifestações culturais encontram-se perpassadas pela dinâmica do mercado, que estende sua racionalidade não só aos negócios que dão suporte ao festejo e às suas respectivas práticas organizacionais, mas, aos poucos, à totalidade das manifestações culturais, moldando, inclusive, as feições do que se constrói como uma identidade. Assim, temos cada vez mais a identidade do festejo inserida na dinâmica do mercado enquanto local de formação de verdade, na racionalidade do homo øeconomicus e no imperativo do desempenho.

\section{Considerações Finais}

Nossos achados apontam para uma formação discursiva cujos elementos constitutivos revelam a tensão entre a gestão pública e os interesses privados, o que não implica um dualismo, mas uma complexa e dinâmica rede de agentes que ora se complementam, ora se opõem. A formação discursiva encontrada remete à relação autonomia-governo, bem como à expectativa da população de que a municipalidade se responsabilize pela provisão dos recursos necessários à realização do festejo. Para os músicos, carnavalescos e dirigentes de agremiações, o Carnaval mostra-se extremamente profícuo para 
a municipalidade no que diz respeito à arrecadação e ao aquecimento da economia local, e esses ganhos devem-se sobretudo à expertise e ao empenho desses profissionais ao promoverem o festejo. Por outro lado, a municipalidade reserva-se a prerrogativa de restringir sua atuação nesse sentido ao estritamente necessário. Isso cria um descompasso entre a expectativa da população e a ação efetiva da PMO. Esses profissionais carnavalescos reivindicam um melhor suporte da gestão municipal, já que se consideram corresponsáveis pelo sucesso do festejo, ao mesmo tempo em que denunciam a insuficiência do apoio recebido, tanto no que diz respeito às subvenções quanto à eficiência dos procedimentos burocráticos.

Embora essa atuação enxuta do Poder Público pressuponha uma autonomia da população no sentido de converter-se numa efetiva parceira na organização desse evento, pudemos observar que essa suplementação do governo pela população é um território de conflitos e negociações entre população e Poder Público, na medida em que, para a população, esse governo é conduzido de forma inadequada e insuficiente. Observamos, contudo, que essa retração do governo é um aspecto crítico para a inserção de um agente que cada vez mais torna central ao Carnaval olindense: o patrocinador. O patrocínio inserese nessa lacuna, sendo uma fonte de recurso que tanto atende às demandas do Poder Público quanto dos artistas locais, atuando nos níveis micro e macro do festejo. Por outro lado, o ganho paulatino de relevância dessas parcerias com o empresariado exercerá um impacto profundo na forma mesma de experienciar o festejo, na medida em que, para além do patrocínio, novos formatos de negócios inseremse no evento. Essa tendência, que começa a se acentuar na década de 1990, quando a figura do patrocinador torna-se uma peça-chave, passa a deparar-se com certa resistência nos anos 2000, quando a consolidação da oferta de camarotes leva a sociedade a questionar essa segregação.

A premissa do homo exconomicus orienta a racionalidade governamental, em que o governo do festejo torna-se cada vez mais difuso. Por outro lado, a mediação de interesses entre as mais diversas células do homo æeconomicus é uma atribuição que desafia a gestão pública. No caso do Carnaval de Olinda, pudemos observar que cada vez mais a Prefeitura busca cooptar o cidadão e o folião como parceiro, na medida em que busca ofertar o um mix segmentado e abrangente de tradições, minimizando as ações de resistência.

Com isso, desenha-se uma complexa rede de públicos de interesse em torno do Carnaval de Olinda. Ao posicionar-se como realizadora de um evento de grande magnitude e tratá-lo como um empreendimento, a Prefeitura Municipal vislumbra não só o incremento de arrecadação, como também o fortalecimento de sua imagem institucional e, ainda, o fortalecimento do turismo, que tem no Carnaval o principal atrativo. Dessa forma, o folguedo popular, agora megaevento, converte-se num ativo, pelo qual a gestão pública formata um portfólio de produtos e serviços, implementa ações de marketing e insere o festejo num processo de troca. Com isso, as manifestações carnavalescas passam a ser integrantes desse mix, e os significados partilhados ao longo das gerações inserem-se numa proposta de entrega de valor.

Embora a década de 1980 já assinale a busca de soluções para fazer jus ao volume crescente de visitantes, é na década de 1990 que a ação da municipalidade assume uma lógica empresarial, buscando obter uma performance competitiva. A tendência que se consolida nessa década permanece ao longo de todo o período investigado, colocando novos desafios na medida em que as proporções que o evento atingiu supersaturam a infraestrutura urbana e os serviços públicos, comprometendo o bem-estar das populações locais. Isso sugere a primazia da orientação mercadológica sobre o bem-estar social e a preservação do patrimônio material e cultural, revelando a existência de duas esferas dificilmente conciliáveis: a do visitante/consumidor, privilegiada em detrimento do morador/cidadão.

O presente estudo apresenta, como limites ao seu escopo, um recuo temporal de quatro décadas, na medida em que o período estudado contempla o início do modelo de festejo então vigente, propiciando a apreensão das transformações e seus impactos nos modos de organizar e experienciar o festejo. Além disso, a opção pelo discurso jornalístico deve-se à sua natureza polifônica, sendo a cobertura dos jornais impressos selecionados uma fonte ao mesmo tempo rica e com a necessária regularidade de periodicidade e pautas. Esses limites, contudo, podem implicar uma limitação, que é o viés decorrente das respectivas linhas editoriais. Foi levando esse aspecto em consideração que optamos por acessar duas fontes, de linhas editoriais distintas. 
Por fim, como contribuição teórica, buscamos trazer a discussão da lógica de mercado e sua interface com uma manifestação cultural com o Carnaval. A contribuição do pensamento foucaultiano nos estudos organizacionais já é bastante reconhecida; dessa forma, partimos desse arcabouço para discutir a dinâmica poder-resistência sob uma perspectiva multidimensional, permitindo contemplar todos as instâncias envolvidas na e pela organização de um festejo dessa magnitude. Além disso, uma vez que o Carnaval tem obtido crescente atenção como fenômeno organizacional, buscamos trazer esse olhar para o Carnaval de Olinda, alvo de grande visibilidade turística e midiática, porém ainda incipiente em nosso campo de investigação.

\title{
Agradecimentos
}

O presente trabalho foi realizado com o apoio da Fundação de Amparo à Ciência e Tecnologia do Estado de Pernambuco (Facepe), por meio de bolsa de doutoramento concedida conforme processo IBPG-0766-6.02/12.

\section{Nota}

\begin{abstract}
${ }^{1}$ Existem diversas acepções para o termo governo sendo, muitas vezes, este sobreposto ao ente da Administração Pública que pratica o ato ou a ação de governar. Veiga-Neto, A. (2005). Governo ou governamento. Currículo sem Fronteiras, 5(2), $79-85$. propõe o resgate do termo governamento nas traduções da obra foucaultiana. De acordo com o autor, o vocábulo governo possui duas acepções na obra de Foucault, a de instituição que governa e de ato de governar em si, para os quais o filósofo usava gouverne e gouvernement, respectivamente. Assim, tendo em vista a adoção do termo governo para ambos os sentidos, esclarecemos que a acepção aqui assumida é mais próxima de gouvernement, ou seja, o ato de conduzir condutas, seja ele de um entre da Administração Pública ou não.
\end{abstract}

\section{Material Suplementar}

Todos os dados e materiais foram disponibilizados publicamente por meio da plataforma Zenodo e podem ser acessados em: Suélen Matozo Franco, \& André Luiz Maranhão de Souza Leão. (2018, September 10). Analytical procedure. Zenodo. http://doi.org/10.5281/zenodo.1412806

\section{Contribuições}

$1^{\circ}$ autor: Elaboração do problema de pesquisa; revisão de literatura; coleta dos dados; análise dos dados; interpretação dos resultados; redação do artigo.

$2^{\circ}$ autor: Elaboração do problema de pesquisa; indicação da teoria; definição do método; validação da análise dos dados; interpretação dos resultados.

\section{Referências}

Andrade, D. P., \& Ota, N. K. (2015). Uma alternativa ao neoliberalismo: Entrevista com Pierre Dardot e Christian Laval. Tempo Social, 27(1), 275-315. http://dx.doi.org/10.1590/0103-207020150115

Araújo, R. C. B. de (1996). Festas: Máscaras do tempo. Entrudo, mascarada e frevo no Carnaval do Recife. Recife: Fundação de Cultura Cidade do Recife. 
Ashenden, S. (2015). Foucault, Ferguson, and civil society. Foucault Studies, (20), 36-51.

Ataíde, J. (1982). Olinda, Carnaval e povo: 1900-1981. Olinda: Fundação Centro de Preservação dos Sítios Históricos de Olinda.

Avelino, N. (2016). Foucault e a recionalidade (neo)liberal. Revista Brasileira de Ciência Política, (21), 229-286. http://dx.doi.org/10.1590/0103-335220162107

Barreto, J. C. (2008). De Montmartre nordestina a mercado persa de luxo: o Sítio Histórico de Olinda e a participação dos moradores na salvaguarda do patrimônio cultural (Dissertação de mestrado não publicada). Universidade Federal de Pernambuco, Recife, PE, Brasil.

Brasileiro, K. V. B. R. (2016). A cultura como produto midiático: Práticas comunicacionais de empresas que utilizam a Lei Rouanet (Dissertação de mestrado não publicada). Faculdade Casper Líbero, São Paulo, SP, Brasil.

Calkin, S. (2015). "Tapping" women for post-crisis capitalism. International Feminist Journal of Politics, 17(4), 611-629. http://dx.doi.org/10.1080/14616742.2015.1071994

Chantepie, P., Becut, A., \& Ratiu, D. E. (2015). Culture, market and society: Between marketization of culture and culturalização of market. International Review of Social Research, 5(2), 75-77. http://dx.doi.org/10.1515/irsr-2015-0006

Cockayne, D. G. (2016). Entrepreneurial affect: Attachment to work practice in San Francisco's digital media sector. Environment and Planning D: Society and Space, 34(3), 1.18. http://dx.doi.org/10.1177/0263775815618399

Dardot, P., \& Laval, C. (2016). A nova razão do mundo: Ensaio sobre a sociedade neoliberal. São Paulo: Boitempo.

Dreyfus, H. L., \& Rabinow, P. (2011). Michel Foucault, uma trajetória filosófica: Para além do estruturalismo e da hermenêtica. Rio de Janeiro: Forense.

Farias, E. (2006). O desfile e a cidade: O carnaval-espetáculo carioca. Rio de Janeiro: E-papers.

Ferreira, L. F. (2005). O livro de ouro do carnaval brasileiro (Vol. 1). Rio de Janeiro: Ediouro.

Flew, T. (2015). Foucault, Weber, neoliberalism and the politics of governmentality. Theory, Culture and Society, 32(7/8), 317-326. http://dx.doi.org/10.1177/0263276415607605

Foucault, M. (2008a). Segurança, território, população: Curso dado no Collège de France (1977-1978). São Paulo: Martins Fontes.

Foucault, M. (2008b). Nascimento da biopolítica: Curso dado no Collège de France (1978-1979). São Paulo: Martins Fontes.

Foucault, M. (2014a). Arqueologia do saber (8a ed.). Rio de Janeiro: Forense Universitária.

Foucault, M. (2014b). História da sexualidade: A vontade de saber. São Paulo: Paz e Terra.

Foucault, M. (2015). Microfísica do poder (2a ed.). Rio de Janeiro: Paz e Terra.

Müller, M. (2015). What makes an event a mega-event? Definitions and sizes. Leisure Studies, 34, 627642. http://dx.doi.org/10.1080/02614367.2014.993333

Hansen, M. B., \& Lindholst, A. C. (2016). Marketization revisited. International Journal of Public Sector Management, 29(5), 398-408. http://dx.doi.org/10.1108/IJPSM-05-2016-0090 
Harchambois, A. M., \& Pontual, V. (2007). As ameaças do Carnaval de massa ao patrimônio de Olinda. Olinda: Centro de Estudos Avançados de Conservação Integrada.

Hollanda, B. B. B. de (2013). País do Carnaval! País do Carnaval? (Uma apresentação alentada ao dossiê: Carnavais \& Organizações). Organizações \& Sociedade, 20(64), 99-109. http://dx.doi.org/10.1590/S1984-92302013000100007

Leal, W. B. (2008). Olinda: 100 anos de frevo. Recife: Publikimagem.

Leão, A. L. M. S., Mello, S. C. B., \& Vieira, R. S. G. (2009). O papel da teoria no método de pesquisa em Administração. Organizações em Contexto, 5(10), 1-16. http://dx.doi.org/10.15603/19828756/roc.v5n10p1-16

Lei $n^{\circ}$ 5.306, de 28 de dezembro de 2001. (2001). Dispõe sobre os festejos carnavalescos no Município e dá outras providências. Olinda, PE: Câmara Municipal de Olinda.

Lei $n^{\circ}$ 8.313, de 23 de dezembro de 1991. (1991). Restabelece princípios da Lei $n^{\circ} 7.505$, de 2 de julho de 1986, institui o Programa Nacional de Apoio à Cultura (Pronac) e dá outras providências. Brasília, DF: Casa Civil.

McAlexander, J. H., Dufault, B. L., Martin, D. M., \& Schouten, J. W. (2014). The marketization of religion: Field, capital, and consumer identity. Journal of Consumer Research, 41(3), 858-875. http://dx.doi.org/10.1086/677894

McGuigan, J. (2014). The neoliberal self. Culture Unbound, 6, 223-240. http://dx.doi.org/10.3384/cu.2000.1525.146223

Miguez, P. (2012). O Carnaval da Bahia: Um desafio para as políticas culturais. Repertório, (19), 136138.

Secretaria de Comunicação. (2016, fevereiro 11). Olinda comemora Carnaval alegre e de paz. Recuperado em 25 de abril, 2016, de http://www.olinda.pe.gov.br/carnaval-de-olinda/olindacomemora-carnaval-alegre-e-de-paz\#.WXF5zojyu00

Özgün, A., Dholakia, N., \& Atik, D. (2017). Marketization and Foucault. Global Business Review, 18(3suppl.), S191-S202. http://dx.doi.org/10.1177/0972150917693335

Queiroz, M. I. P. (1992). Carnaval brasileiro: O vivido e o mito. São Paulo: Brasiliense.

Stival, M. L. (2016). Do poder ao governo e do saber a veridição. Discurso, 45(2), 335-344. http://dx.doi.org/10.11606/issn.2318-8863.disc..2015.112523

Santos, F. B. P. dos (2010). Carnaval e administração pública: O papel dos governos locais na configuração das festas. Textos escolhidos de cultura e arte populares, Rio de Janeiro, 7(2), 6174. http://dx.doi.org/10.12957/tecap.2010.12026

Thiry-Cherques, H. R. (2010). À moda de Foucault: Um exame das estratégias arqueológica e genealógica de investigação. Lua Nova: Revista de Cultura e Política, (81), 215-148. http://dx.doi.org/10.1590/S0102-64452010000300009

Tucherman, I. (2007). Michel Foucault, hoje ou ainda: Do dispositivo de vigilância ao dispositivo de exposição da intimidade. In A. Queiroz \& N. V. Cruz (Orgs.), Foucault hoje? (pp. 108-118). Rio de Janeiro: 7Letras, 2007.

Vallas, S. P., \& Cummins, E. R. (2015). Personal branding and identity norms in the popular business press: Enterprise culture in age of precarity. Organization Studies, 36(3), 293-319. http://dx.doi.org/10.1177/0170840614563741 
Yates, S. (2015). Neoliberalism and disability: The possibilities and limitations of Foucauldian critique. Foucault Studies, (19), 84-107. http://dx.doi.org/10.22439/fs.v0i19.4826

\section{Dados dos Autores}

Suélen Matozo Franco

Av. Prof. Moraes Rego, 1235, Cidade Universitária, 50670-901, Recife, PE, Brasil.

E-mail: suelenmfranco@gmail.com.

André Luiz Maranhão de Souza Leão

Av. Prof. Moraes Rego, 1235, Cidade Universitária, 50670-901, Recife, PE, Brasil.

E-mail: aleao21@ hotmail.com 